\title{
An Analysis of the Agreement between Child Self Reports and Parental Proxy Reports of the Health Related Quality of Life of 4-7 Year-Old Children with Corrosive Esophagus Burn
}

\section{Korozif Özefagus Yanığı Olan 4-7 Yaș Arası Çocukların Sağlıkla Ilgili Yașam Kalitesinin Değerlendirilmesinde Öznel Değerlendirme ve Ebeveyn Değerlendirmesi Arasındaki Uyumun Incelenmesi}

\author{
Gülden Yörükoğlu1, Hatice Bal Yılmaz2 \\ ${ }^{1}$ Bakırköy Dr. Sadi Konuk Education and Research Hospital, Istanbul, Turkey \\ 2Ege University Faculty of Nursing, Izmir, Turkey
}

\begin{abstract}
Aim: This study aims to investigate the agreement between child self reports and parental proxy reports of the health related quality of life of 4-7 year-old children with corrosive esophagus burn.

Materials and Methods: The sample of this descriptive study consisted of 100 4-7 year-old children with corrosive esophagus burn and their parents. The study data were collected with a Child Information Form, a Parent Information Form, and 4-7 year-old Kiddy-KINDL child and parental forms. Results: It was reported that there was no statistically significant difference between the quality of life scores in child self report forms and parental proxy report forms $(Z=0.131, p=0.896, p>0.05)$ but there was a strong and statistically significant and meaningful correlation between the mean scores of the two groups $(r=0.86, p=0.000, p<0.001)$.

Conclusion: The study results suggested an agreement between the child self reports and parental Proxy reports of the health related quality of life of 4-7 year-old children with corrosive esophagus burn.
\end{abstract}

Key Words: Corrosive substance burn, quality of life, child

\section{ÖZET}

Amaç: Bu araştırma korozif özefagus yanı̆̆ı olan 4-7 yaş arası çocukların yaşam kalitesinin değerlendirilmesinde öznel değerlendirme ve ebeveyn değerlendirmesi arasındaki uyumun incelenmesi amacı ile yapılmışıı. Gereç ve Yöntemler: Tanımlayııı tipte yapılan bu araştırmanın örneklemini, 4-7 yaş arasında korozif özefagus yanığı olan 100 çocuk ve anneleri oluşturmuştur. Araşıırmada veri toplama aracı olarak, "Çocuk Tanıtım Formu", "Ebeveyn Tanıtım Formu" ve Çocuk ve ebeveynin çocuğun yaşam kalitesini değerlendirmesine yönelik "4-7 yaş Kiddy-KINDL (Children Quality of LifeQestionnaire)" çocuk ve ebeveyn formları kullanılmışır.

Bulgular: Çocukların değerlendirdiği öznel yaşam kalitesi puan ortalaması ile annelerin değerlendirdiği yaşam kalitesi puan ortalamaları arasında istatistiksel olarak anlamlı fark olmadığı ( $Z=0,131, p=0,896, p>0,05)$, iki ölçüm puanları arasında pozitif yönde, güçlü ve istatistiksel olarak ileri düzeyde anlamlı bir ilişki olduğu belirlenmiş̧tir $(r=0,86, p=0,000, p<0,001)$.

Sonuç: Klinik olarak korozif özefagus yanı̆̆ı olan $4-7$ yaş arası çocukların sağıkla ilgili yaşam kalitesinin değerlendirmesinde öznel değerlendirme ve ebeveyn değerlendirmesi arasında uyum saptanmıştır.

Anahtar Kelimeler: Korozif madde yanık, yaşam kalitesi, çocuk 


\section{Introduction}

According to a recent World Health Organization (WHO) report on preventing childhood injuries, the leading five causes are enlisted as traffic accidents, drowning, burns, falls and poisonings (1). Poisoning has been reported as a significant health problem common in childhood and, indeed, is often preventable (1-3). Chemical substances commonly used at homes for a variety of purposes in developing and even developed countries can easily be reached by children, which consequently cause poisoning accidents. However, study data on a global scale concerning poisonings caused by home chemicals are still not available. It has already been noted that more than 120.000 children under 6 years old in the United States in 2004 accidentally ingested ammonia, bleach and liquid detergents. In a relevant study, it was also reported that children under 12 years old in Bangladesh, Colombia, Egypt, and Pakistan were commonly poisoned with medicine $(31 \%)$ and detergents $(20 \%)$ that were easily accessible to them at home (1). No epidemiological studies have been conducted on preventable childhood poisonings in Turkey so far (4).

Children are often directly exposed to injuries as they are unable to control their behavior or to identify potential risks at home. A strong correlation has been found between a child's age, physical and mental development, interaction with other people, and home accidents they are involved in (1). Poisoning is commonly reported in children under 5 years old $(1,3,5)$ since children in this age group are quite enthusiastic and curious to experience and learn new things (4).

Children under 5 years old often ingest liquid detergents which eventually cause terrible esophagus burn $(3,5)$. Esophagus burn in children is a serious complication that results in perforation, fistuls in veins, stomach penetration, and esophageal stricture (3). Esophageal stricture produced by scar tissue during the treatment of burn also causes low health related quality of life, morbidity, and even mortality (1).

WHO defines Quality of Life (QoL) as individuals' perception of their position in life in the context of the culture and value systems in which they live and a broad ranging concept affecting the person's physical health, psychological state, level of independence, social relationships, personal beliefs and their relationship to salient features of their environment (6). HealthRelated Quality of Life (HROOL), is expressed as subjective perception of the patients' satisfaction with their health $(7,8)$. Patients' own perceptions are of vital importance in the evaluation of (HROOL). Therefore, it is deliberately suggested to use subjective scales in order to enable the patients to evaluate their own medical condition (9).

It might be challenging to evaluate the quality of life of young children. If the child is too young or unable to respond due to a medical condition like mental retardation, quality of life assessment is often carried out by parents or caregivers (9). Grange et al. (10) conducted a survey to analyze generic scales to measure the quality of life particularly developed for children under 5 years old between 1980-2005 and highlighted parental forms of the HRQOL scales may be the best choice for children under 8 years old to measure the health related quality of life or mental health.

Corrosive esophagus burn is a chronic problem that requires long term medical and surgical treatment which will certainly influence both children and their parents adversely. A majority of studies on children with corrosive esophagus burn are either descriptive or particularly focus on prognosis and surgical operations (11). A review of the recent studies indicated no relevant studies on the quality of life of children with corrosive esophagus burn, which suggested the fact that it is utterly significant to investigate the agreement between the child self reports and parental proxy reports of the quality of life.

\section{Materials and Methods}

This study aimed to analyze the agreement between the child self reports and parent-proxy reports of HRQOL in 4-7 year-old children with corrosive esophagus burn.

The present study addresses the following research questions:

Research Question 1: Is there a statistically significant correlation between the child self reports and parent proxy reports of the HRQOL in 4-7 year-old children with corrosive esophagus burn?

\section{Hypothesis}

$\mathrm{H1}$ : The child self reports and parent proxy reports of the $\mathrm{HROOL}$ in 4-7 year-old children with corrosive esophagus burn are consistent.

\section{Design}

This study is descriptive and cross-sectional. The study data were collected between 1st May-30th November 2010 at pediatric surgery units and outpatients clinics of two hospitals (Ege University Faculty of Medicine, and Dr. Behçet Uz Children's Hospital) located in Izmir, Turkey.

\section{Participants}

The sample group of the study consisted of 100 children between 4-7 years old (Ege University Faculty of Medicine $n=18$; and Dr. Behçet Uz Children's Hospital $n=82$ ) monitored in the pediatric surgery units and outpatients clinics in these hospitals and their mothers. The participants were selected by inclusion criteria and consented to participate in the study.

Inclusion Criteria:

- Children must be 4-7 years old

- The child's burn must be graded as stage 2a and above according to Di Costanzo Grading System

- The child must be diagnosed with esophagus burn at least 3 months previously.

- The child should not have mental retardation.

\section{Tools and Materials}

The study data were collected with a Child Information Form, a Parent Information Form, and Kiddy-KINDL Health Related Quality of Life Scale for 4-7 year-old children, child and parent forms.

\section{Child Information Form}

Child Information Form was developed by the researcher based on information in the relevant literature $(2,11,12)$ consisting 
of 17 questions aimed at determining sociodemographic characteristics of children (age, sex, educational status), the course of prognosis and treatment procedures (the date of corrosive substance intake, the date of diagnosis, the season when the child ingested the chemical substance, the type of chemical substance, the place where the child ingested the substance, whether or not the substance had been kept in its original package, the first aid method that was applied, burn area and its depth, treatment stage, duration of hospitalization, whether or not dilatation was applied, whether or not the child had gastrostomy, chemical substances that children ingested).

\section{Parent Information Form}

Parent Information form included 10 items enquiring about sociodemographic characteristics (mother's age, educational status, the place where she spent most of her life (urban areas or rural areas), family type, family income, profession, social security status, number of people in her house) and the moment of incidence (where she was when her child ingested the substance, what she exactly did when she realized her child had ingested the substance).

\section{Kiddy-KINDL-Child Form}

KINDL (KINDER Lemensqualitatsfragebogen: Children Quality of Life-Questionnaire) for children was first developed by Bullinger in 1994 in German in order to evaluate the changes in the quality of life peculiar to children's varying age groups and it was revised by Ravens-Sieberer and Bullinger in 1998 as KINDLR. KINDL scale is available in three different versions based on the self-report methods in different age groups, namely Kiddy-KINDL for 4-7 year-old children (applied by the interviewer), Kid-KINDL for 8-12 year-old children and Kiddo-KINDL for 13-16 year-old adolescents. Additionally there are two parent forms with which parents can indirectly evaluate the quality of life of their young children (4-7 years old) as well as older children and adolescent children (8-16 years old) $(7,13,14)$.

Kiddy-KINDL scale is a 3 point (1=never, $2=$ sometimes, $3=$ quite often) and includes 6 subscales: physical well-being, emotional well-being, self-esteem, family, peers and school (school or kindergarden where daily activities take place) and 2 items in each subscale and 12 items in total. In addition to those 6 subscales, there is also a disease subscale that includes 6 items. Higher scores indicate a good health related quality of life. KINDL has proved its efficiency both in clinical use and outside the clinic on healthy children and children with chronical health problems $(7,13)$. Cronbach alpha coefficient was found to be 0.76 for the Turkish version of the form developed by Saatlı et al. (15).

\section{Kiddy-KINDL for 4-7 year-old Children-Parent Form}

Kiddy-KINDL for parents is a 5 point ( $1=$ never, $2=$ rarely, 3=sometimes, 4=often, 5=always) and includes 6 subscales, physical well-being, emotional well-being, self-esteem, family, peers and school and 4 items in each subscale and 24 items in total. In addition to those 6 subscales, there is also a disease subscale that includes 6 items. There is also one more subscale in, "further significant concerns" with 22 items to enable parents to evaluate their child's quality of life in detail. The scores of each subscale and the total scores are converted into a 0-100 point scale $(7,13)$. Saatlı et al. (15) found Cronbach alpha coefficient as
0.84 for the parent form of the scale. The correlation coefficient was 0.50 between the quality of life total scores of parents and children $(p<0.01)$.

\section{Data Collection Method}

Written parental informed consent was obtained before participants took part in the study. Having explained the purpose and the method of the study to children, the researchers conducted face to face interviews with children and filled in the Child Information Form and Kiddy-KINDL for 4-7 year-old childrenChild Form.

The Parent Information Form and Kiddy-KINDL for 4-7 yearold children-Parent Form were delivered to the mothers to be completed individually. Since only mothers were allowed to stay with their children at the hospitals where the study was carried out, the study included only mothers.

\section{Data Analysis}

The data obtained were evaluated via SPSS 16.0 software. Descriptive statistics for Child Information Form and Parent Information Form were used. Independent Sample t-test, Mann Whitney U-test and Kruskal-Wallis test were used to examine the relationship between dependent and independent variables. Kiddy-KINDL child self reports and Kiddy-KINDL parental proxy reports mean scores were analyzed by Sperman correlation analysis. Classroom correlation and Wilcoxon Signed Rank test were used to determine the consistency between the mean scores of Kiddy-KINDL child self reports and Kiddy-KINDL parental proxy reports.

\section{Ethical Considerations}

The permissions in writing were sought from the Board of Management at Ege University, the Institute of Health Sciences, the Board of Ethics at Ege University, Faculty of Nursing, and the hospital management as well as the authors who tested the scale for its Turkish validity and reliability.

\section{Results}

The majority of the children participating in the study were male $(62 \%), 63$ children were under 5 years old ( 4 and 7 years old, $5.5 \pm 0.2$ ) and $64 \%$ of them had never been to school. Thirtyfour percent of the mothers were aged between 30-34 years old (32.5 \pm 0.9 ). Educatioanal background of the mothers was diverse. Thirty percent were high school graduates and 59\% did not work. Thirty percent of all participants lived in cities and $44 \%$ of mothers had extended families. It was finally stated that $48 \%$ of them had 2 children and $55 \%$ of participant mothers had no social security.

The incidents of substance intake were also analyzed and it was noted that $53 \%$ of the children were four years old at the time of the event, $43 \%$ ingested the substance in spring, $74 \%$ ingested the corrosive substance at home, and $71 \%$ of all the children ingested acidic substances. It was also noted that the chemical substances were not being kept in their original packages in $66 \%$ of the incidents and $83 \%$ of the mothers were at home when their children ingested the corrosive substance. Sixty-nine percent of the children were immediately taken to hospital and $67 \%$ of them were diagnosed with a stage 2 a burn. 
Findings showed that $44 \%$ of the children were hospitalized for 7 months or longer and $51.5 \%$ of them were dilatated for $1-3$ times. Also $90 \%$ of the children had surgical operations, $37 \%$ had gastrostomy, $18 \%$ could not ingest solid food, and $95 \%$ of the children needed constant medication.

The total scores of Kiddy-KINDL scale of children and parents were analyzed and it was found that the quality of life total score was $34.55 \pm 21.78$ according to the child self reports while it was $34.11 \pm 20.78$ according to the evaluation of mothers (Table I).

The comparative analysis did not indicate any statistically significant difference between children's self reports and mothers' reports of the GoL ( $Z=0.131, p=0.896, p>0.05$ ) (Table II).

The total scores of Kiddy-KINDL child self reports and KiddyKINDL parental proxy reports were analyzed and it was found that there was a positive, strong and statistically high significant correlation between the two scores $(r=0.86, p=0.000, p<0.001)$ (Figure 1).

\section{Discussion}

Corrosive burn caused by caustic intake usually occurs among children under 5 years old and more often among children around 2 years old since children at that age are curious about liquids in bottles and drink them while they are too young to distinguish poisonous liquids (12). It has recently been reported that $80 \%$ of pediatric cases in the United States were between 1-3 years old. It has commonly been accepted that male children and children with mental retardation are in the high risk group (16). Conk et al. (16) conducted a relevant study and found that $68.8 \%$ of the children in the study were male while Ceylan (12) found $63.2 \%$, Cankorkmaz et al. (17) found 62.2\%, Doruk et al.

Table I. Health-Related Quality of Life Kiddy-KINDL of child and parent scale and subscales' mean scores

\begin{tabular}{|l|l|l|l|l|l|}
\hline Kiddy-KINDL child & N & Min. & Max. & Mean & ISD \\
\hline Total scores & 100 & 10.00 & 95.00 & 34.55 & 21.78 \\
\hline Physical health & 100 & 0.00 & 93.75 & 21.85 & 27.48 \\
\hline Emotional health & 100 & 5.00 & 90.50 & 34.41 & 26.25 \\
\hline Self-esteem & 100 & 0.00 & 100.00 & 29.57 & 28.98 \\
\hline Family & 100 & 6.25 & 95.00 & 35.22 & 26.64 \\
\hline Friends & 100 & 0.00 & 100.00 & 39.85 & 22.58 \\
\hline School & 47 & 0.00 & 91.50 & 29.58 & 24.26 \\
\hline Chronic disease & 100 & 0.00 & 75.00 & 19.61 & 18.93 \\
\hline Kiddy-KINDL parent & $\mathbf{N}$ & Min. & Max. & Mean & \pm SD \\
\hline Total scores & 100 & 5.98 & 91.67 & 34.11 & 20.38 \\
\hline Physical health & 100 & 0.00 & 93.75 & 22.81 & 28.36 \\
\hline Emotional health & 100 & 0.00 & 87.50 & 32.87 & 24.46 \\
\hline Self-esteem & 100 & 0.00 & 100.00 & 28.37 & 28.37 \\
\hline Family & 100 & 6.25 & 100.00 & 47.31 & 26.41 \\
\hline Friends & 100 & 0.00 & 100.00 & 43.81 & 22.96 \\
\hline School & 47 & 0.00 & 93.75 & 39.62 & 24.73 \\
\hline Chronic disease & 100 & 0.00 & 91.67 & 23.37 & 20.55 \\
\hline
\end{tabular}

(18) found $67 \%$ of the participants were male. The results of this particular study also confirmed that the majority of the children were male and $63 \%$ of them were under 5 years old.

Detergents and cleaning materials are made of sodium or potassium hydroxide, or caustic potash, which may potentially result in serious injuries. Additionally, batteries, when ingested accidentally, may also cause esophagus burns. Since liquid alkaline is commercially available free from any regulations, every year almost 5000 children under 5 years old accidentally ingest the chemical substance $(19,20)$. One of the most common of such chemical materials is bleach that was reported to be ingested by $24.7 \%$ of the children in a study conducted by Karaaslan et al. (21), 43.6\% of the children in the study of Cankorkmaz et al. (17), and $31.2 \%$ of the children in the study of Doruk et al. (18). Moreover, Riffat and Cheng (22) found that $74 \%$ of the children ingested an alkaline substance and Huang et al. (23) similarly stated that $87 \%$ of the children ingested an alkaline substance. The results showed that $71 \%$ of the children in our study ingested an acidic substance. Our study is consistent with other studies.

It has been reported that it was mostly the home of children in urban settings where children ingested corrosive substances Çiftçi et al. (24), which indicates that children might have mistaken such chemical substances for water or fruit juice. Besides the fact that children can easily reach corrosive materials at home, the bottle tops may also cause dangers because they can easily be opened by little children, which suggests that legal regulations are urgently necessary to produce appropriate containers in order to reduce the risks of home accidents $(25,26)$. Riffat and Cheng (22) reported that $76 \%$ of the children ingested the corrosive substance at home while Conk et. al. (16) noted that only $52 \%$ of the children ingested the substance at home. Sarıoglu-Büke

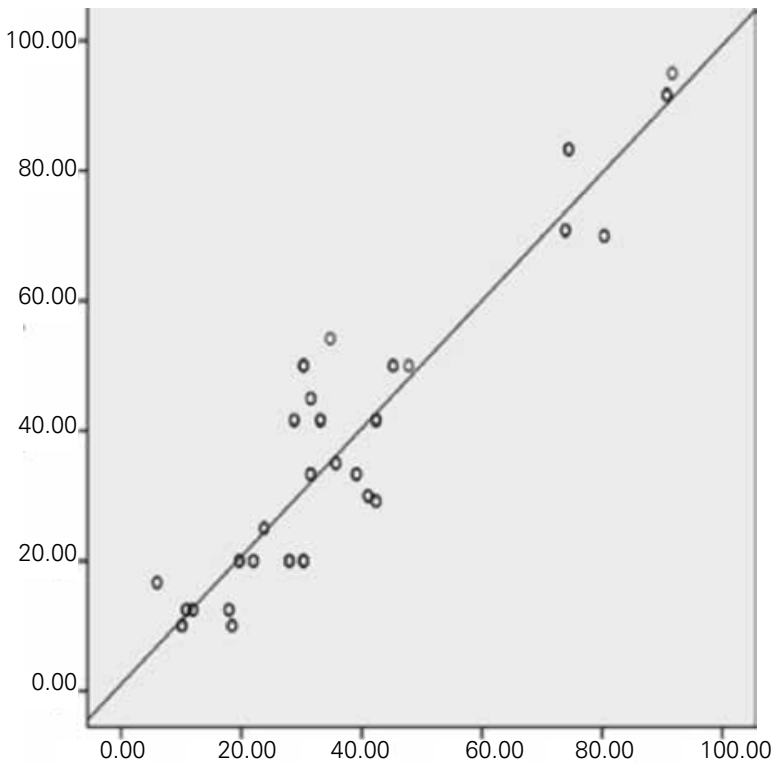

Figure 1. The distribution of scores obtained through Kiddy-KINDL child and Kiddy-KINDL parent 
Table II. Comparison and correlation of Health-Related Quality of Life Kiddy-KINDL child and Kiddy-KINDL parent

\begin{tabular}{|l|l|l|l|l|l|l|l|} 
& N & Mean & 土SD & Z & P & rs $^{*}$ & p \\
\cline { 1 - 4 } Kiddy-KINDL child & 100 & 34.55 & 21.78 & 0.131 & 0.896 & 0.86 & 0.000 \\
\cline { 1 - 5 } & 100 & 34.11 & 20.36 & & & & \\
\hline
\end{tabular}

*Wilcoxon signed-rank test, rs=Spearman rank correlation coefficient

et al. (27) stated that half of the mothers in the study did not buy the detergents in their original packages for their affordable price and stored them in used drink bottles. The findings of our study likewise demonstrated that the chemical substances that children ingested had not been kept in their original packages and that the children ingested the subtance at home, which complied with the results of the previous studies in the field.

Ingesting a chemical substance can cause serious damage in the alimentary canal. The results of our study indicated that $67 \%$ of the children had stage 2a burn. Riffat and Cheng (22) similarly found that $34 \%$ of the children had stage 1 burn and $20 \%$ of them had stage 2 burn while Çördük et al. (28) reported that $42 \%$ of the children had stage 1 burn.

Pediatric corrosive intake is a fatal emergency. However, it may often cause serious complications such as esophagus perforation and require multiple dilatation treatment and esophagus replacement Çiftci et al. (24). Our results showed that a majority of the children had to stay in hospital for a longer period and undergo multiple dilatation and several other surgical operations, which also complied with the results of relevant studies.

Most of the participant mothers in our study were primary school graduate housewives with a lower socioeconomic status. Ceylan (12) stated that $97 \%$ of the mothers were housewives, $65.5 \%$ of whom were primary school graduates. SarıogluBüke et al. (27) also found that a majority of parents had lower socioeconomic and educational status. According to these results we think that the childhood injuries are more likely to occur in families. where mothers are less educated and of lower socioeconomic status.

Corrosive esophagus burn related to corrosive substance intake is serious problem that heavily affects the quality of life of children. Evaluation of the quality of life of children can be done with both subjective and objective assessments. The former refers to a child's physical, emotional, and social functions while the latter especially signifies what children can achieve, what their living conditions are, and how they function in their social circles and school as well as their social relations with other people (29). Some researchers particularly prefer child self reports since they can successfully convey the children's own perceptions about their condition while some others emphasize the fact that parental evaluation is much more valuable as it provides an objective assessment $(30,31)$. The debate has not been resolved seemingly although child self reports have become increasingly preferable in relevant studies while assessing the quality of life of children (32). Scales that provide both child and parental forms can be the best option; yet they are quite few in number and child-parent forms cannot be expected to agree with each other in all cases $(33,34)$.

It has been maintained that parental evaluation is necessarily complementary to the child self reports in the assessment of the quality of life in clinical studies (35). The results of recent studies have shown that a statistically significant difference was not found between the child self reports and parental proxy reports and the assessments of both groups agreed well with each other in clinical studies on the quality of life of children with chronic diseases $(20,36,37)$. Reading (35) tested PedQL 4.0 Generic Core scale for its reliability and validity and found that the parent forms of the scale were quite applicable, valid and reliable with children aged between 2-16 years old. Our study has shown that there was no statistically significant difference a between the child self reports and parental proxy reports.

However, there are also controversial studies demonstrating that child self reports and parental proxy reports did not comply with each other due to the variations in the children's physical and mental development and differences in the severity of their medical condition $(38,39)$.

\section{Implications For Nursing Practice}

Corrosive esophageal burns are the cause of longer hospitalization, surgical procedures, failure, in achieving daily activities, growth and development retardation, long treatment process, failure in meeting game requirements and separating oneself from school and friends. All these processes affect the quality of life of children negatively (40). The QoL, allows the evaluation of the effectiveness of nursing care. Nurses can provide good nursing care with a holistic approach and improve the QoL of patients. Therefore, concepts and philosophies related to QoL is important in nursing practice $(41,42)$.

\section{Conclusions}

The HRQOL of children between 4-7 years old with corrosive esophagus burn was analyzed via child self reports and parental proxy reports and both reports were found to be consistent with no statistically significant difference. It is suggested that parental evalution can be especially valuable in the assessment of the quality of life of their children when they are too young to answer or simply unable to respond to the questions in the scale.

Acknowledgement: Extramural funding has not been used in this study, Ethics Committee Approval: The study were approved by the the Board of Ethics at Ege University School of Nursing, Informed Consent: Consent form was filled out by all participants, Concept: Gülden Yörükoğlu, Hatice Bal Yılmaz, Design: Gülden Yörükoğlu, Hatice Bal Yılmaz, Data Collection or Processing: Gülden Yörükoğlu, Analysis or Interpretation: Gülden Yörükoğlu, Hatice Bal Yılmaz, Literature Search: Gülden Yörükoğlu, Writing: Gülden Yörükoğlu, Peer-review: External and Internal peer-reviewed, Conflict of Interest: No conflict of interest was declared by the authors, Financial Disclosure: The authors declared that this study has received no financial support. 


\section{References}

1. Peden M, Oyegbite K, Ozanne-Smith J, Hyder AA, Branche $\mathrm{C}$, Rahman AKM F, et al. World report on child injury prevention. (2008). Retrieved from http://whqlibdoc.who.int/ publications/2008/9789241563574_eng.pdf?ua=1

2. Kayaalp L, Odabaşı G, Doğangün, B, Cavusoglu P, Bolat N, Bakan $\mathrm{M}$, et al. Corrosive esophagitis in children: social and psychological aspects. Türk Pediatri Arşivi 2006; 41:24-30.

3. Janous`ek P, Kabelka Z, Rygl M, Lesnc P, Grabec P, Fajstavr J, et al. Corrosive injury of the oesophagus in children. International Journal of Pediatric Otorhinolaryngology 2006; 70:1103-7.

4. Güven A. Dangers to children at home: corrosive esophageal burn. TAF Prev Med Bull 2008; 7:535-40.

5. Afzal NA, Albert $D$, Thomas AL, Thomson, M. A Child with oesophageal strictures. Lancet 2002; 359:1032.

6. World Health Organization-WHO. Measuring Quality of Life. 1997. Retrieved from http://www.who.int/mental_health/media/68.pdf

7. Eser E, Yüksel H, Baydur H, Erhart M, Saatli G, Cengiz Ozyurt $\mathrm{B}$, et al. The psychometric properties of the new turkish generic health-related quality of life questionnaire for children (KidKINDL). Turk Psikiyatri Derg 2008; 19:409-17.

8. Yardımcı F, Bolışık B, Altıparmak S, Bal Yılmaz H. Agreement between self reports and parent reports of health-related quality of life in children aged 4-7. SSTB Dergisi 2012; 2:17-28.

9. Sagheri D, Ravens-Sieberer U, Braumann B, Mackensen S. An evaluation of health-related quality of life (HROoL) in a group of 4-7 year-old children with cleft lip and palate. J Orofac Orthop 2009; 70:274-84

10. Grange A, Bekker $H$, Noyes J, Langley P. Adequacy of healthrelated quality of life measures in children under 5 years old: systematic review. Journal of Advanced Nursing 2007; 59:197220.

11. Çam H, Kıray E, Taştan Y, Çerçi ÖY. Poisoning cases follow in child health and disease emergency department of Istanbul university faculty of medicine. Türk Pediatri Arşivi 2003; 38:2339.

12. Ceylan Ö. The assesment of social, demographic and endoscopic findings of infants with corrosive agent ingestion. 2008. Şişli Etfal Training and Research Hospital, Expertise Thesis, Istanbul.

13. KINDL. Retrieved from http://kindl.org/english/information/. Access Date: January 2, 2010.

14. Ravens-Sieberer $U$, Bullinger $M$. Assessing health related quality of life in chronically ill children with the German KINDL: first psychometric and content analytical results. Qual Life Res 1998; 7:399-407.

15. Saatı G, Baydur H, Eser E, Yüksel $H$. Validity and reliability study of KIDDY-KINDL 4-7 age quality of life scale. Poster. 2. Quality of Life Congress on Health, April 5-7 2007, Izmir.

16. Conk Z, Bal Yılmaz H, Şen D, Erdoğdu M. Evaluation of children with corrosive substance drink and determination of family applied methods until admitted to hospital. Ege Üniversitesi Hemşirelik Yüksekokulu Dergisi 2004; 20:1-9.

17. Cankorkmaz L, Köylüoğlu G, Güney C. Children with corrosive esophageal burns and esophagoscopy. Çocuk Cerrahisi Dergisi 2009; 23:110-3.

18. Doruk D, Narcı A, Korkmaz M, Koltuksuz U, Özkaraca E. Effects of the types of corrosive materials and patient age on the degree of corrosive esophagitis. Kocatepe Tip Dergisi 2007; 8:9-14.

19. Bautista Casasnovas A, Estevez Martinez E, Varela Cives R, Villanueva Jeremias A, Tojo Sierra R, Cadranel S. A retrospective analysis ingestion of caustic substances by chidren, Eur J Pediatr 1997; 156:410-4

20. Durualp E, Kara FN, Yılmaz V, Alaybeyoğlu K. Comparison of Life Qualities According to the Views of Children and Parents with and without Chronic Disease. Ankara Universitesi Tıp Fakültesi Mecmuası 2010; 63:55-63.
21. Karaarslan B, Turla A, Aydın B. Corrosive poisoning cases consulted at ondokuz mayıs üniversity faculty of medicine, emergency service. Van Tip Dergisi 2007; 14:109-13.

22. Riffat $F$, Cheng $A$. Pediatric caustic ingestion: 50 consecutive cases and a review of the literature. Diseases of the Esophagus 2009; 22:89-94.

23. Huang $\mathrm{YC}, \mathrm{Ni} \mathrm{YH}$, Lai HS, Chang $\mathrm{MH}$. Corrosive esophagitisin children. Pediatr Surg Int 2004; 20:207-10.

24. Çiftci $A O$, Şenocak ME, Büyükpamukcu N, Hiçsönmez, A. Gastric outlet obstruction due to corrosive ingestion: incidence and outcome. Pediatr Surg Int 1999; 15:88-91.

25. Doğan Y, Erkan T, Çokuğraş FC, Kutlu T. Caustic gastroesophageal lesions in childhood: an analysis of 473 cases. Clin Pediatr (Phila) 2006; 45:435-8.

26. Kasap E, Özütemiz Ö. Pet bottle danger: Corrosive esophagitis. Güncel Gastroenteroloji 2006; 10:29-35.

27. Sarioğlu-Büke $A$, Çördük $N$, Ateşci $F$, Karabul M, Koltuksuz U. A different aspect of corrosive ingestion in children: Sociodemographic characteristics and effect of family functioning. International Journal of Pediatric Otorhinolaryngology 2006; 70:1791-8.

28. Çördük N, Sarıoğlu-Büke A, Bağcı Ș, Acar K, Herek Ö, Koltuksuz $U$. Economic impact and judicial consequences of corrosive ingestion in children. Çocuk Cerrahisi Dergisi 2009; 23:114-9.

29. Çamur D, Özcebe H, Altundağ Y, Altunöz U, Aydın EF, Tiryaki C. Evaluation of quality of life in adolescents with Kiddo-Kindl scale. 2. Quality of Life Congress on Health, 2007. Abstract Book, 130.

30. Aksu M. Evaluation of sociodemographic features, depression, anxiety, problem solving ability and quality of life of the parents of the children who have chronic illness. Istanbul Haydarpasa Numune Training and Research Hospital, Family Medicine Departmant, Expertise Thesis, 2008. Istanbul.

31. Bowling A. Measuring health. A review of quality of life measurement scales. 2. Ed., Open University Press, 1998. Buckingham.

32. Aydemir Ö. Using in clinical practice quality of life in the health. Sağlıkta Birikim 2006; 1:9-13.

33. Dolgun G, Savaşer S. Development of quality of life scalein 8-12 age children with attention deficit hyperactivity disorder (Poster Presentation). 1. Quality of Life in Health Symposium Program, 2004. Abstract Book, 84

34. Erdoğan A, Karaman MG. The recognition and management of psychological problems among child and adolescent with chronic and fatal disease. Anadolu Psikiyatri Dergisi 2008; 9:244-52.

35. Reading R. Parental-proxy report of their children's health-relsted quality of life: an anaysis of 13878 parental's reliability and validity across age subgroups using the PedsQL 4.0 Generic Core Scales. Child: Care, Health and Development 2007; 33:649-50.

36. Memik NÇ, Ağaoğlu B, Çoşkun A, Hatun Ş, Ayaz M, Karakaya I. Evaluation of quality of life in children and adolescents with type 1 diabetes mellitus. Çocuk ve Gençlik Ruh Sağlığı Dergisi 2007; 14:133-8.

37. Mitchell W, Clarke S, Sloper P. Care and support needs of children and young people with cancer and their parentals. Psychooncology 2006; 15:805-16.

38. Cremeens J, Eiser C, Blades M. Chracteristics of health-related self-report measures for children aged three to eight years: $A$ review of the literature. Qual Life Res 2006; 15:739-54.

39. Chang $\mathrm{PC}$, Yeh $\mathrm{CH}$. Agreement between child self-report and parentalproxy- report to evaluate quality of life in children with cancer. Psychooncology 2004; 14:125-34.

40. Upton P, Lawford J, Eiser C. Parent-child agreement across child health-related quality of life instruments: a review of the literature. Qual Life Res 2008; 17:895-913.

41. Eser E. Conceptual foundations and measurement of health related quality of life. Sağlıkta Birikim 2006; 1:1-8.

42. Mollaoğlu M. Quality of life in chronic illness and nursing. 2. Quality of Life Congress on Health, 2007. Abstract Book, 9-10. 